\title{
Identification of a novel S6K1 inhibitor, rosmarinic acid methyl ester, for treating cisplatin-resistant cervical cancer
}

\author{
Ki Hong Nam ${ }^{\dagger}$, Sang Ah Yi ${ }^{\dagger}$, Gibeom Nam, Jae Sung Noh, Jong Woo Park, Min Gyu Lee, Jee Hun Park, \\ Hwamok Oh, Jieun Lee, Kang Ro Lee, Hyun-Ju Park, Jaecheol Lee and Jeung-Whan Han*
}

\begin{abstract}
Background: The mTOR/S6K1 signaling pathway is often activated in cervical cancer, and thus considered a molecular target for cervical cancer therapies. Inhibiting mTOR is cytotoxic to cervical cancer cells and creates a synergistic anti-tumor effect with conventional chemotherapy agents. In this study, we identified a novel S6K1 inhibitor, rosmarinic acid methyl ester (RAME) for the use of therapeutic agent against cervical cancer.

Methods: Combined structure- and ligand-based virtual screening was employed to identify novel S6K1 inhibitors among the in house natural product library. In vitro kinase assay and immunoblot assay was used to examine the effects of RAME on S6K1 signaling pathway. Lipidation of LC3 and mRNA levels of ATG genes were observed to investigate RAME-mediated autophagy. PARP cleavage, mRNA levels of apoptotic genes, and cell survival was measured to examine RAME-mediated apoptosis.

Results: RAME was identified as a novel S6K1 inhibitor through the virtual screening. RAME, not rosmarinic acid, effectively reduced mTOR-mediated S6K1 activation and the kinase activity of S6K1 by blocking the interaction between S6K1 and mTOR. Treatment of cervical cancer cells with RAME promoted autophagy and apoptosis, decreasing cell survival rate. Furthermore, we observed that combination treatment with RAME and cisplatin greatly enhanced the anti-tumor effect in cisplatin-resistant cervical cancer cells, which was likely due to mTOR/S6K1 inhibition-mediated autophagy and apoptosis.
\end{abstract}

Conclusions: Our findings suggest that inhibition of S6K1 by RAME can induce autophagy and apoptosis in cervical cancer cells, and provide a potential option for cervical cancer treatment, particularly when combined with cisplatin.

Keywords: Rosmarinic acid methyl ester, S6K1, Autophagy, Apoptosis, Cervical cancer, Cisplatin resistance

\section{Background}

Cervical cancer is one of the most common malignant gynaecological tumors and is primarily caused by persistent human papilloma virus (HPV) infection [1]. Although effective vaccines against high-risk HPV strains significantly lower the occurrence of cervical cancer, these vaccines have only prophylactic effects without therapeutic effects against HPV-infected lesions [2, 3]. The currently existing remedies for cervical cancer are surgery, chemoradiotherapy, or both; however, these

\footnotetext{
* Correspondence: jhhan551@skku.edu

${ }^{+} \mathrm{Ki}$ Hong Nam and Sang Ah. Yi contributed equally to this work.

School of Pharmacy, Sungkyunkwan University, Suwon 16419, Republic of Korea
}

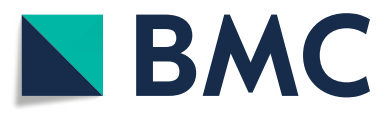

(๑) The Author(s). 2019 Open Access This article is distributed under the terms of the Creative Commons Attribution 4.0 International License (http://creativecommons.org/licenses/by/4.0/), which permits unrestricted use, distribution, and

reproduction in any medium, provided you give appropriate credit to the original author(s) and the source, provide a link to the Creative Commons license, and indicate if changes were made. The Creative Commons Public Domain Dedication waiver (http://creativecommons.org/publicdomain/zero/1.0/) applies to the data made available in this article, unless otherwise stated.

options are limited in patients with metastatic or recurrent cervical cancers after platinum-based chemoradiotherapy [4-6]. Therefore, the development of targeted therapeutics utilizing pathological mechanisms is necessary to cure advanced or recurrent cervical cancer.

The HPV infection-mediated pathogenesis of cervical cancer is closely related to the activation of multiple intracellular signaling pathways $[7,8]$. The mammalian target of rapamycin (mTOR) is one such signaling molecule that has been reported to be activated in cervical cancer [8-12]. Immunostaining analyses have shown that p-mTOR, pp70S6K1, and p-S6 are highly detected in HPV-positive lesions and cervical cancer cell lines [9-12], and these contribute to the survival of cervical cancer cells [11]. 
Pharmaceutical inhibition of this signaling cascade in mice and cell lines effectively suppressed tumorigenesis, cell growth, and proliferation of cervical cancer cells [12-14]. These findings have demonstrated that the mTOR/S6K1 signaling pathway can be used as a prognostic marker or therapeutic target for cervical cancer treatment.

Cisplatin, a platinum-based drug, is a primary chemotherapeutic agent that is used in combination with radiotherapy to treat cervical cancer $[15,16]$. Unfortunately, the frequent acquisition of resistance to cisplatin in cervical cancer patients is a major cause of therapeutic failure [17]. Among the multifactorial mechanisms underlying chemoresistance, overexpression or activation of the Akt/ mTOR pathway critically contributes to cisplatin resistance by attenuating p53 activity $[18,19]$. The majority of studies have suggested that co-treatment with an mTOR inhibitor including rapamycin greatly enhanced the therapeutic activity of cisplatin against several cisplatin resistant cell lines, causing activation of autophagy and subsequent apoptosis [9, 14, 19-24]. As the broad action of rapamycin can cause unexpected side effects, seeking more specific inhibitor is considered to be an effective way to overcome cisplatin resistance.

Here, we performed structure-based screening of single compound library and identified that rosmarinic acid methyl ester (RAME) is a potent inhibitor of the mTOR/S6K1 signaling pathway. RAME treatment of cervical cancer cells effectively inhibited activation of S6K1 as well as the kinase activity of S6K1. We also observed an increase in autophagy and apoptotic cell death after RAME treatment in cervical cancer cell lines. Moreover, co-treatment of RAME with cisplatin sensitized cisplatin-resistant cervical cancer cell line and synergistically caused the induction of autophagy and apoptosis. Collectively, our findings revealed that RAME, a natural-derived compound, is a candidate therapeutic substance for cervical cancer patients, particularly for those whose cancer displayed cisplatin resistance.

\section{Methods}

\section{Reagents}

Anti-p70 S6K1 (Santa Cruz Biotechnology, Dallas, TX; SC-230), anti-phospho (T389) p70 S6K1 (Cell Signaling Technology, Danvers, MA; \#9205), anti-S6 (Cell Signaling Technology; \#2217), anti-phospho (S235/236) S6 (Cell Signaling Technology; \#4856), anti-GFP (Santa Cruz Biotechnology; SC-9996), anti-PARP-1 (Santa Cruz Biotechnology; SC-7150), anti-Akt1/2/3 (Santa Cruz Biotechnology; SC-8312), anti-phospho (S473) Akt (Santa Cruz biotechnology; SC-7958), anti-LC3B (Cell Signaling Technology; \#2775), anti-p53 (Santa Cruz Biotechnology, Dallas; SC-126), and anti-actin (Millipore, Temecula, CA; mab1501) antibodies were utilized in this study.

\section{Cell culture}

HeLa (ATCC ${ }^{\bullet}$ CCL-2), A549 (ATCC ${ }^{\bullet}$ CCL-185), H1299 (ATCC ${ }^{\circ}$ CRL-5803) cells were obtained from the American Type Culture Collection (ATCC) and $\mathrm{SiHa}$ cells (ATCC ${ }^{\odot}$ HTB-35) were generous gifts from Jung-Hye Choi (Kyung Hee University), who obtained the cells from ATCC. The cells were cultured as indicated in the instructions from ATCC and were grown under a fully humidified atmosphere of $95 \%$ air and $5 \% \mathrm{CO}_{2}$ at $37^{\circ} \mathrm{C}$. Cells grown to $80-90 \%$ confluency was used for assays.

\section{Knockdown of S6K1}

For the knockdown of S6K1, HeLa cells were transfected with siRNA targeting S6K1 using Lipofectamine 2000 reagent (Life Technologies) according to the manufacturer's protocol. The siRNA sequences targeting S6K1 are as follow: forward, $5^{\prime}$-CACCCUUUCAUUGUGGAC CUGAUUU-3' and reverse, 5'-AAAUCAGGUCCACA AUGAAAGGGUG-3'.

\section{Virtual screening of natural product compound library}

The docking screening was carried out using the Sybyl-X 2.1.1 package in Windows 7. The X-ray structure of the S6K1 kinase domain (PDB ID: 3WE4) [25] complexed with PF-470871 was downloaded from the RCSB Protein Data Bank (http:/www.rcsb.org/pdb/home/home.do). The structure was refined as follows: all water molecules were removed, the ligand was extracted, and the protein structure was optimized with the protein preparation module in Sybyl using the default parameters. The Surflex-Dock module embedded in Sybyl was used to conduct a docking screening of the in-house library containing 519 natural product compounds. The X-ray pose of bound ligand PF-470871 was assigned to generate the protomol, which defines the receptor's binding cavity in which docked ligands are aligned. Protomol was generated with a threshold parameter of 0.50 and a bloat parameter of $0 \AA$. The main setting was 50 solutions per compound, and other parameters accepted the SurflexDock Geom default settings. The scoring function for Surflex-Dock is trained to estimate the dissociation constant $\left(K_{d}\right)$ expressed in $-\log K_{d}$ units. The final hitlist compounds were selected after evaluating for binding by combining the consensus scoring function CScore (consensus score $>3$ ), Surflex-Dock total score (>8), and Lipinski's rule-of-five filter. Similarity-based virtual screening was conducted using flexible ligand superpositioning algorithm FlexS implanted in Sybyl [26]. The X-ray pose of PF-470871(PDB ID: 3WE4) was used as the template molecule. A higher similarity score represented a greater similarity of a tested molecule to the template molecule (maximum score is 10.0).

\section{Immunoblotting}

The cells were lysed in Pro-Prep (iNtRON Biotechnology, Korea) and centrifuged at 13,000 rpm for $18 \mathrm{~min}$. 
For immunoblotting, proteins of each sample were separated through SDS-polyacrylamide gel electrophoresis (PAGE). The proteins were transferred to polyvinylidene difluoride (PVDF) membranes with a semi-dry transfer apparatus (Bio-Rad, Hercules, CA). The membranes were incubated overnight with the indicated primary antibodies, then incubated with horseradish peroxidase-conjugated secondary antibodies for $1 \mathrm{~h}$ (Abcam). The signals were detected through chemiluminescence reagents (AbClon, Korea) and quantified with ImageJ program.

\section{Immunofluorescence}

For the ectopic expression of the LC3B vectors, HeLa and $\mathrm{SiHa}$ cells were transfected with GFP-LC3B vectors using Lipofectamine 2000 reagent (Invitrogen, Carlsbad, CA), according to the manufacturer's instructions. After $24 \mathrm{~h}$, cells were fixed in $4 \$$ paraformaldehyde and then GFP signal from ectopically expressed LC3B was observed using confocal microscope (Olympus FV-1000 confocal laser scanning microscope) with an Apochromat $60 \times$ objective.

\section{Quantitative real-time PCR (qPCR)}

RNA extracts were prepared as previously described [27]. To extract total RNA, cells were lysed in Easy-Blue reagent (iNtRON Biotechnology). Then, $1 \mu \mathrm{g}$ of total RNA was reversely transcribed into cDNA using a Reverse Transcription kit (Promega, USA). Quantitative real-time PCR was performed using KAPATM SYBR FAST qPCR (KAPABIOSYSTEMS) with the CFX $96^{\text {mo }}$ or Chromo $4^{\text {ma }}$ real-time PCR detector (Bio-Rad). The relative mRNA levels were normalised to the GAPDH mRNA levels for each reaction. The qPCR primer sequences used are as follow: GAPDH forward, 5 '-GAGTCAACGGATTT GGTCGT-3'; GAPDH reverse, 5'-TTGATTTTGGAGGG ATCTCG-3'; ULK1 forward, 5'-GGACACCATCAGGC TCTTCC-3'; ULK1 reverse, 5'-GAAGCC GAAGTCAG CGATCT-3'; ATG5 forward, 5'-AGCAACTCTGGATG GGATTG-3'; ATG5 reverse, 5'-CACTGCAGAGGTGT TTCCAA-3'; BECN1 forward, 5'-AACCTCAGCCGAAG ACTGAA-3'; BECN1 reverse, 5'-GACGTTGAGCTGAG TGTCCA-3'; ATG7 forward, 5'-ACCCAGAAGAAGCT GAACGA-3'; ATG7 reverse, 5'-AGACAGAGGGCAGG ATAGCA-3'; ATG12 forward, 5' -GGCAGTAGAGCGAA CACGAA-3'; ATG12 reverse, 5'-GGGAAGGAGCAAAG GACTGA-3'; ATG13 forward, 5' -CCCAGGACAGAAAG GACCTG-3'; ATG13 reverse, 5'-AACCAATCTGAACC CGTTGG-3'; Bax forward, 5' -TCTACTTTGCCAGCAA ACTGG-3'; Bax reverse, 5'-TGTCCAGCCCATGATG GTTCT-3'; Noxa forward, 5'-AGAGCTGGAAGTCGAG TGT-3'; Noxa reverse, 5'-GCACCTTCACATTCCT CTC-3'; Puma forward, 5'-GACCTCAACGCACAGTA3'; Puma reverse, 5'-CTAATTGGGCTCCATCT-3'; Gadd45 $\alpha$ forward, 5'-TGCGAGAACGACATCAACAT-
3'; Gadd45 $\alpha$ reverse, 5'-TCCCGGCAAAAACAAATA AG-3'; $p 21$ forward, 5'-CACCGAGACACCACTGGA GG-3'; $p 21$ reverse, $5^{\prime}$-GAGAAGATCAGCCGGCGTTT$3^{\prime}$; $14-3-3 \sigma$ forward, 5' -TTTCCTCTCCAGACTGACAA ACTGTT-3'; 14-3-3 $\sigma$ reverse, 5' -TAGAACTGAGCTGC AGCTGTAAA-3'.

\section{Cell viability assay}

HeLa and SiHa cells were plated in 6 well plates at a density of $6 \times 10^{5}$ and $2 \times 10^{5}$ cells per well, respectively. Cells were treated with DMSO or RAME $(40,80 \mu \mathrm{M})$ for 24 and $48 \mathrm{~h}$ before the cells were counted. For cell counting, cells trypsinized using Trypsin EDTA were counted using a haemocytometer.

\section{In vitro kinase assay}

In vitro kinase assay was performed as previously described [27]. Briefly, recombinant S6K1 (R\&D systems, Minneapolis, MN; 896-KS), GST-S6 (Abnova, Taipei city, Taiwan; H00006194-P01), and H2B (BioLabs, MA, USA; $\mathrm{M} 2505 \mathrm{~S}$ ) were used. The reactions were performed in the presence of $100 \mu \mathrm{M}$ adenosine triphosphate (ATP) and kinase reaction buffer $[25 \mathrm{mM}$ Tris- $\mathrm{HCl}(\mathrm{pH} 7.5), 5$ $\mathrm{mM} \beta$-glycerophosphate, $2 \mathrm{mM}$ dithiothreitol (DTT), $0.1 \mathrm{mM} \mathrm{Na} \mathrm{VO}_{4}, 10 \mathrm{mM} \mathrm{MgCl}_{2}$ ] at $37^{\circ} \mathrm{C}$ for $45 \mathrm{~min}$. The reactions were stopped with $5 \times$ Laemmli loading buffer and then subjected to immunoblot analysis.

\section{Clonogenic assay}

For clonogenic assays, $\mathrm{HeLa}$ and $\mathrm{SiHa}$ cells were seeded in $1 \times 10^{3}$ cells per well of a 6 -well plate and cultured in complete media for 10 20 days. Cells were fixed with glutaraldehyde $(6 \%)$, stained with $0.5 \%$ crystal violet, and photographed using a digital scanner. All experiments were performed at least three times. Representative experiments are shown.

\section{Statistical analysis}

Statistical significance was analysed using the Student's $t$-test (two-tailed) and assessed based on the $P$-value.

\section{Results}

RAME is identified as a novel S6K1 inhibitor by virtual screening of the natural product compound library

To identify novel S6K1 inhibitors, we conducted a virtual screening of the in-house library containing 519 compounds isolated from natural products. We employed both docking-based screening and a similarity-based search method to select the candidate compounds (Fig. 1a). First, Surflex-Dock docking was performed against the X-ray structure S6K1 kinase domain (PDB ID: 3WE4) and 17 candidate compounds were selected, considering their binding energy scores and drug-like properties (Table 1). Next, we used the FlexS program for 


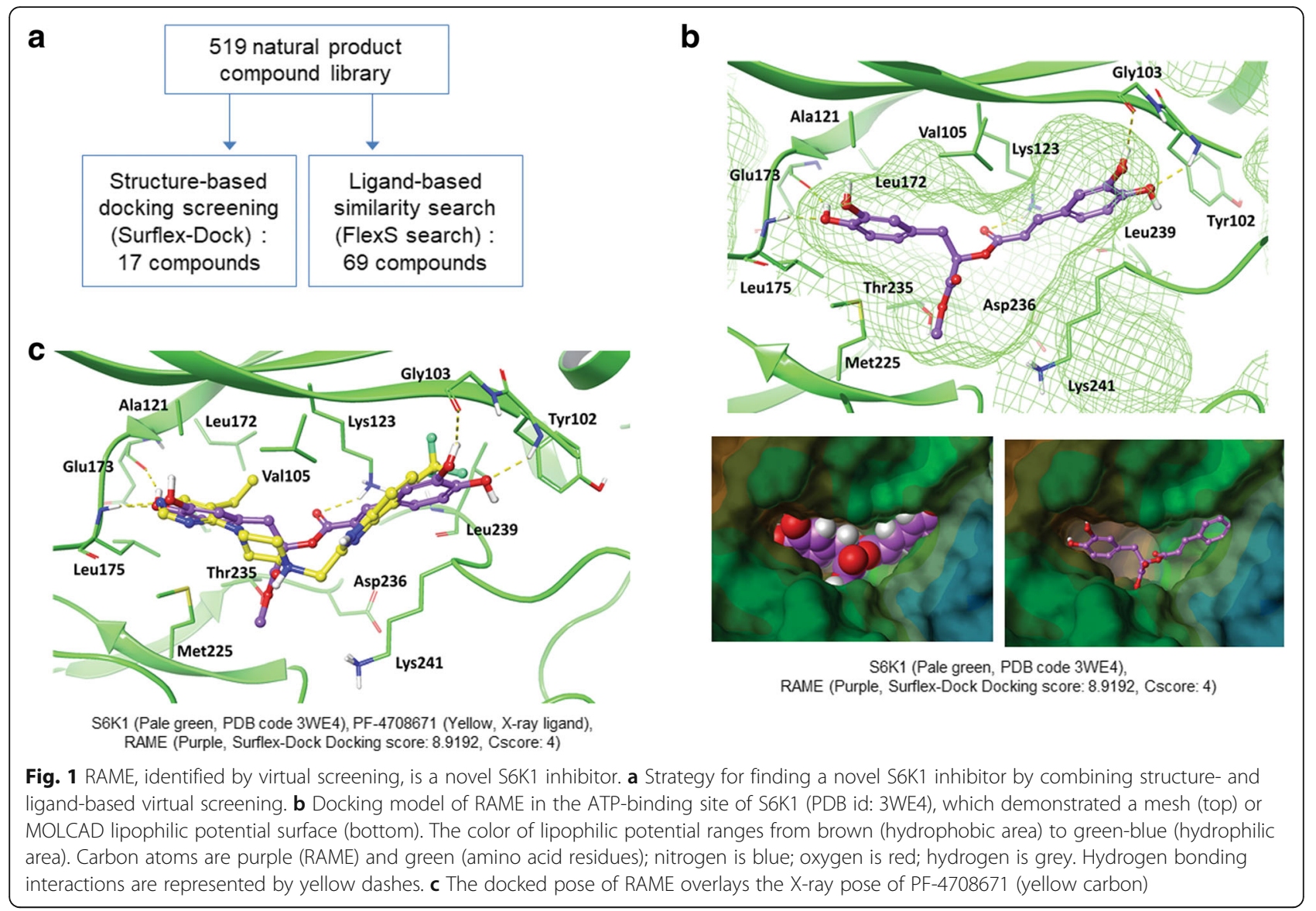

Table 1 Hit list 17 compounds selected by Surflex-Dock docking analysis

\begin{tabular}{|c|c|c|c|c|c|c|c|c|c|c|c|c|}
\hline \multicolumn{13}{|c|}{ Selected 17 compounds (Total Score > 8 and C score $>3$ ) } \\
\hline \multicolumn{9}{|c|}{ Surflex-Dock Docking Results } & \multicolumn{4}{|c|}{ Lipinski's Properties } \\
\hline Name & $\begin{array}{l}\text { Total } \\
\text { Score }\end{array}$ & Crash & Polar & D score & $\begin{array}{l}\text { PMF } \\
\text { score }\end{array}$ & G score & $\begin{array}{l}\text { Chem } \\
\text { score }\end{array}$ & C score & $\begin{array}{l}\text { H-bond } \\
\text { Acceptor }\end{array}$ & $\begin{array}{l}\text { H-bond } \\
\text { Donor }\end{array}$ & $\begin{array}{l}\text { Molecular } \\
\text { weight }\end{array}$ & CLogP \\
\hline AMC8 & 8.3455 & -2.1334 & 3.1423 & -150.1913 & -13.5711 & -92.1301 & -23.2483 & 4 & 6 & 3 & 343.3737 & 2.2664 \\
\hline BBE4 & 8.0406 & -1.684 & 5.2925 & -118.3739 & -9.5793 & -205.3034 & -22.8193 & 4 & 4 & 3 & 285.3377 & 1.782 \\
\hline$J C 24$ & 8.6122 & -2.588 & 4.8921 & -142.4306 & -49.9801 & -227.2735 & -22.9057 & 4 & 8 & 4 & 390.3839 & 0.7192 \\
\hline JSYB21 & 9.122 & -3.9792 & 4.8938 & -196.7893 & 9.5743 & -279.8751 & -15.2224 & 4 & 13 & 6 & 478.4444 & -2.0499 \\
\hline JSYB4 (RA) & 8.4245 & -2.2637 & 7.6215 & -127.2991 & -17.5161 & -184.1398 & -20.575 & 4 & 8 & 5 & 360.3148 & 1.0996 \\
\hline KR_BK_10 & 8.0976 & -0.9089 & 3.8661 & -127.2817 & -26.3626 & -220.0721 & -21.0439 & 5 & 7 & 4 & 378.4162 & 0.7522 \\
\hline KR_BK_16 & 8.4383 & -0.6405 & 3.648 & -123.7665 & -14.3909 & -188.1732 & -20.8374 & 5 & 6 & 3 & 360.401 & 1.6347 \\
\hline KR_BM_41 & 8.1458 & -0.6331 & 5.9054 & -113.8569 & -42.814 & -115.0421 & -23.1057 & 4 & 7 & 5 & 302.2357 & 1.5037 \\
\hline KR_CT_11 & 8.1698 & -2.3809 & 1.0128 & -148.0841 & 14.7862 & -253.8318 & -18.5355 & 5 & 8 & 0 & 469.5268 & 3.0063 \\
\hline KR_HV_6 & 9.3254 & -3.3264 & 4.8485 & -153.1333 & 21.5821 & -286.7884 & -14.5041 & 4 & 10 & 6 & 416.4196 & -1.1732 \\
\hline KR_HV_8 & 8.5056 & -2.7215 & 4.3782 & -155.9434 & 20.9705 & -231.0792 & -15.0293 & 4 & 10 & 6 & 422.4673 & -0.0712 \\
\hline KR_HV_9 & 9.3382 & -2.5547 & 4.3424 & -152.7992 & 1.4948 & -265.2069 & -12.6789 & 5 & 10 & 6 & 415.4117 & -1.2102 \\
\hline KR_TR_6 & 8.3868 & -1.8635 & 5.3265 & -133.4614 & -16.3225 & -214.3578 & -26.3579 & 5 & 5 & 3 & 313.3478 & 2.4172 \\
\hline SKB54 & 8.1219 & -4.7382 & 6.1257 & -206.3804 & -25.3407 & -297.2112 & -12.7596 & 5 & 12 & 8 & 448.4184 & -2.2472 \\
\hline SRE10 (RAME) & 8.9192 & -1.7056 & 5.7246 & -138.018 & -15.4552 & -206.3927 & -20.5586 & 4 & 8 & 4 & 374.3414 & 1.3942 \\
\hline TBDE6 & 8.0693 & -1.0091 & 7.043 & -112.1842 & -36.4047 & -40.4333 & -26.3986 & 4 & 7 & 5 & 302.2357 & 1.5037 \\
\hline WBCC44 & 8.9582 & -3.684 & 3.125 & -178.3426 & 19.0338 & -289.5232 & -21.5875 & 4 & 11 & 4 & 466.4352 & 0.3119 \\
\hline
\end{tabular}


flexible superpositioning of all the database compounds onto the rigid X-ray pose of PF-4708671 (PDB ID: 3WE4). From there, 69 compounds with similarity over $65 \%$ were selected (Table 2). The hit lists obtained from the two virtual screening methods were quite different and just two compounds (KR_CT_11 and RAME) were identified as high-ranking hits from both methods (Additional file: Figure S1). Then, we visually inspected the binding interactions between ligand and S6K1 kinase domain focusing on the hinge region, which is important for inhibitor activity. Only RAME (R-enantiomer) occupied the hinge region and formed hydrogen bonds with Glu173 and Leu175 (Fig. 1b), whereas KR_CT_11 did not fit into this region. As illustrated in Fig. 1b and c, the left-side catechol group faced the hinge region, and one $\mathrm{OH}$ group formed bidentate hydrogen bonds with the backbone carbonyl oxygen of Glu173 and the backbone amide $\mathrm{NH}$ of Leu175. The aromatic ring was surrounded by hydrophobic residues, such as Ala121, Leu172, and Met225, forming hydrophobic and van der Waals interactions. The methyl group of the methyl ester was involved in hydrophobic contact with the side chain of Met225, which could not be formed by RA. Two OH groups on the right-side catechol formed hydrogen bonds with Gly103 and Tyr102. In addition, the carbonyl oxygen atom of the central ester linker also formed a hydrogen bond with the side chain amine of Lys123. Overall, the docked pose of RAME appeared to be similar to the X-ray pose of PF-4708671
(Fig. 1c), but RAME formed more extensive polar interactions in the same active site of the S6K1 kinase domain [25]. These findings encouraged us to investigate the effects of RAME on S6K1 and its downstream signaling.

\section{RAME, not RA, inhibits the phosphorylation of S6 by S6K1} Based on the binding pose of RAME, we decided to evaluate the regulatory activity of RAME, compared with its parent compound rosmarinic acid (RA) (Fig. 2a). To evaluate whether RAME and RA affect the kinase activity of S6K1 in vitro, we conducted an in vitro kinase assay using recombinant S6K1 with GST-S6 protein as a substrate. RAME inhibited the phosphorylation of S6 in dose-dependent manner (Fig. 2b), but RA did not affect the S6K1-mediated phosphorylation of S6 (Fig. 2c, d). The phosphorylation of H2B S36, another representative S6K1 target [27], was also inhibited by incubation with RAME, as observed by in vitro kinase assay with recombinant $\mathrm{H} 2 \mathrm{~B}$ protein (Additional file 1: Figure S2). Next, we examined whether RAME and RA inhibit S6K1 activity also in vivo, by treating cervical cancer cell lines with RAME and RA $(80 \mu \mathrm{M})$ for $24 \mathrm{~h}$. In immunoblotting, RAME, not RA, inhibited phosphorylation of S6 (Fig. 2e). These in vitro and in vivo data indicated that methyl residue in RAME caused S6K1 inhibitory effects different from those of RA and $80 \mu \mathrm{M}$ was the optimal concentration of RAME to fully inhibit S6K1 activity.

Table 2 List of compounds with FlexS similarity score higher than 6.5. (The score of template molecule PF-4708671 = 10)

\begin{tabular}{|c|c|c|c|c|c|c|c|c|c|c|c|}
\hline 1 & $\mathrm{BBC} 32$ & 7.7308 & 21 & KR_CW_4 & 7.3366 & 41 & KR_CT_1 & 6.9312 & 61 & JC32 & 6.6894 \\
\hline 2 & $\mathrm{TOH} 27$ & 7.6826 & 22 & LY2584702 & 7.2976 & 42 & $\mathrm{TOH} 30$ & 6.9239 & 62 & KR_PC_19 & 6.6871 \\
\hline 3 & KR_GE_56 & 7.6669 & 23 & KR_CW_3 & 7.2956 & 43 & JGCC121 & 6.9237 & 63 & SRE10 & 6.6444 \\
\hline 4 & KR_PK_25 & 7.6421 & 24 & $\mathrm{TOH} 37$ & 7.2726 & 44 & DG2 & 6.9233 & 64 & BSCC31 & 6.6342 \\
\hline 5 & KR_CW_7 & 7.6234 & 25 & KR_PC_1 & 7.2496 & 45 & $\mathrm{TOH} 25$ & 6.9217 & 65 & BSCC6 & 6.6272 \\
\hline 6 & KR_PK_18 & 7.621 & 26 & $\mathrm{JC} 1$ & 7.2219 & 46 & KR_CW_1 & 6.898 & 66 & PMBC2 & 6.6152 \\
\hline 7 & $\mathrm{BBH} 3$ & 7.6062 & 27 & KR_PK_2 & 7.2159 & 47 & KR_PC_12 & 6.8931 & 67 & KR_BK_30 & 6.576 \\
\hline 8 & $\mathrm{BBC7}$ & 7.6062 & 28 & PFE5 & 7.2075 & 48 & KR_CT_2 & 6.8671 & 68 & KR_BK_13 & 6.5618 \\
\hline 9 & KR_GE_52 & 7.5701 & 29 & KR_CT_13 & 7.1872 & 49 & KR_CT_4 & 6.8218 & 69 & KR_HV_11 & 6.5519 \\
\hline 10 & $\mathrm{BBC} 33$ & 7.503 & 30 & KR_CW_2 & 7.1569 & 50 & KR_CT_5 & 6.8207 & & & \\
\hline 11 & KR_CT_3 & 7.4814 & 31 & KR_CW_9 & 7.1418 & 51 & KR_CT_10 & 6.8103 & & & \\
\hline 12 & KR_CT_12 & 7.471 & 32 & KR_PK_15 & 7.0917 & 52 & Pfizer & 6.7808 & & & \\
\hline 13 & KR_PK_23 & 7.4528 & 33 & $\mathrm{BKHC1}$ & 7.0725 & 53 & Lilly & 6.772 & & & \\
\hline 14 & JC8 & 7.4419 & 34 & KR_CT_11 & 7.0143 & 54 & $\mathrm{JC} 12$ & 6.7711 & & & \\
\hline 15 & KR_CT_7 & 7.3919 & 35 & KR_LA_1 & 6.9976 & 55 & KR_CT3 & 6.7694 & & & \\
\hline 16 & KR_CW_6 & 7.3867 & 36 & KR_PK_19 & 6.9908 & 56 & KR_HV_12 & 6.7583 & & & \\
\hline 17 & JGCC60 & 7.3785 & 37 & JSY1 & 6.9793 & 57 & KR_CT_8 & 6.736 & & & \\
\hline 18 & KR_CT2 & 7.374 & 38 & KR_PGA_3 & 6.9675 & 58 & KR_PN_4 & 6.7145 & & & \\
\hline 19 & KR_GE_53 & 7.3672 & 39 & $5,559,274$ & 6.959 & 59 & KR_BM_48 & 6.7062 & & & \\
\hline 20 & KR_PK_16 & 7.3587 & 40 & KR_PGA_2 & 6.9566 & 60 & $\mathrm{BSCC}_{-}$ & 6.7011 & & & \\
\hline
\end{tabular}




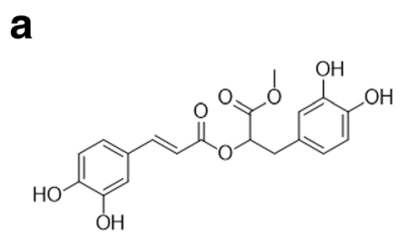

RAME (Rosmarinic acid methyl ester)<smiles>O=C(/C=C/c1ccc(O)c(O)c1)OC(Cc1ccc(O)c(O)c1)C(=O)O</smiles>

RA (Rosmarinic acid)

d

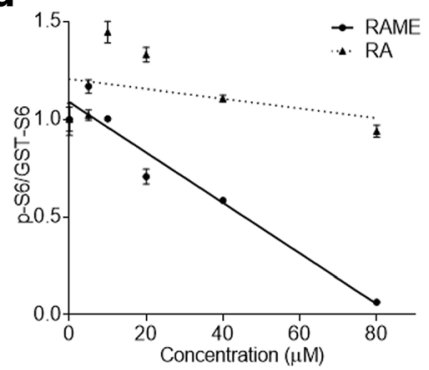

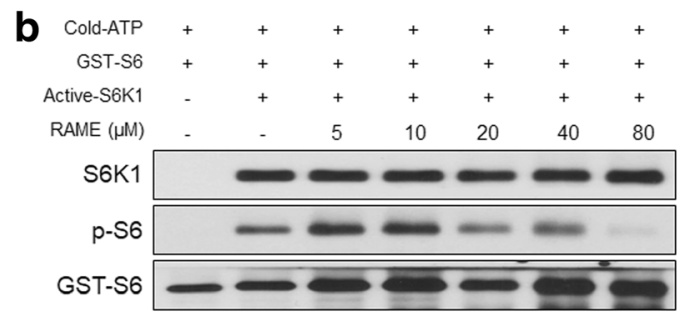

C

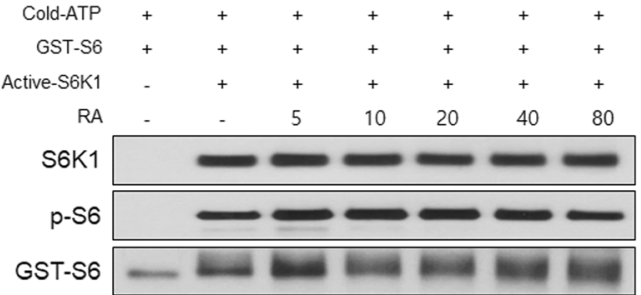

e

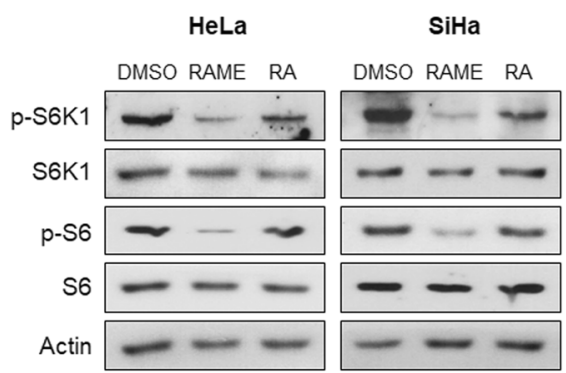

Fig. 2 RAME, not RA, inhibits kinase activity of S6K1 in vitro and in vivo. a Structures of RAME and RA. b and $\mathbf{c}$ The in vitro kinase assay with RAME (b) or RA (c) was performed in a dose dependent manner using recombinant GST-S6, active S6K1, and cold-ATP. d Quantitative graph of (b and c). e Immunoblotting analysis of HeLa (left) and SiHa (right) cells treated with RAME $(80 \mu \mathrm{M})$ or RA $(80 \mu \mathrm{M})$ for $24 \mathrm{~h}$

Similarly, RAME treatment for $24 \mathrm{~h}$ dose-dependently reduced phosphorylation of S6 in cervical and lung cancer cells (Fig. 3a; Additional file 1: Figure S3). However, acute treatment with RAME did not show inhibitory effects on S6 phosphorylation, despite declined phosphorylated S6K1 (Fig. 3b). A prior study demonstrated that PF-4708671 inhibited S6K1 activity, but stimulated S6K1 phosphorylation, which was dependent upon mTORC1 [28]. Unlike PF-4708671, RAME decreased the mTORdependent phosphorylation of S6K1 T389 in a dosedependent manner (Fig. 3a, c). mTOR is an enzymatic subunit of both mTORC1 and mTORC2. To investigate the effect of RAME on the enzymatic activity of mTOR, we assessed the phosphorylation of Akt, a substrate of mTORC2, after RAME treatment. Unlike that of S6K1, phosphorylation of Akt was not affected by RAME (Fig. 3c), whereas PF-4708671 increased the level of phosphorylated Akt (Additional file 1: Figure S4). Given that mTOR interacts with and phosphorylates S6K1, we performed a co-immunoprecipitation assay to determine whether the association between mTOR and S6K1 is interrupted by
RAME. RAME inhibited S6K1 from interacting with mTOR and S6 (Fig. 3d). These data indicate that RAME effectively inhibits phosphorylation of S6K1 and S6 by blocking the interaction between S6K1 and mTOR.

\section{RAME induces autophagy in cervical cancer cells}

Autophagy is induced during stress or nutrient deprivation states. Through autophagy, the cell facilitates the degradation of damaged cellular components and obtains molecular building blocks and energy [29]. The mTOR/S6K1 pathway is a central regulator of cell growth and proliferation. Additionally, several studies have shown that mTOR and S6K1 inhibits autophagy $[30,31]$. The enhancement of a microtubule associated protein light chain 3 (LC3) family members is a marker of cell autophagy activation [32]. Autophagic activity is measured by the conversion of non-lipidated LC3-I to lipidated LC3-II [33]. To examine the effect of RAME on the autophagic process, cervical cancer cell lines (HeLa and SiHa) were transfected with GFP-LC3 and treated with RAME for $24 \mathrm{~h}$. LC3-I and LC3-II were 


\section{a}

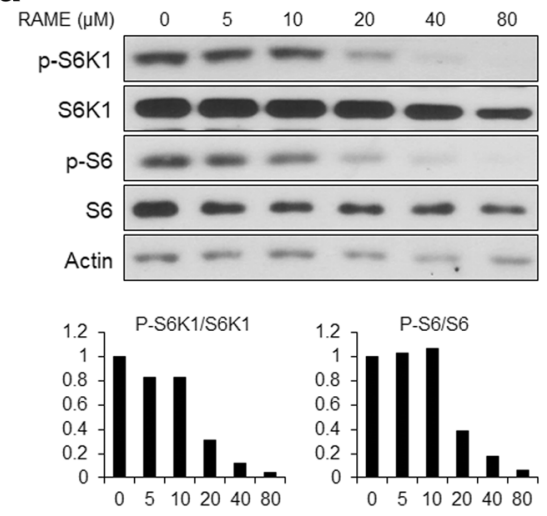

C

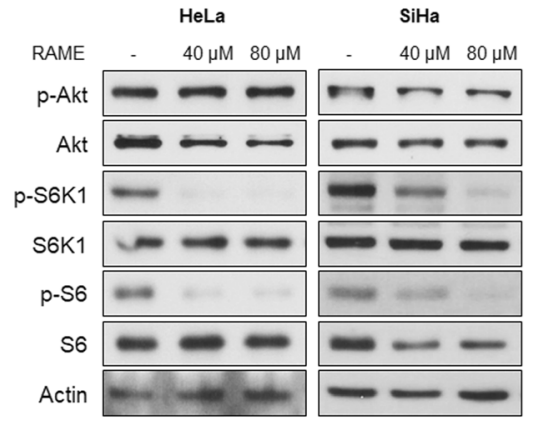

b

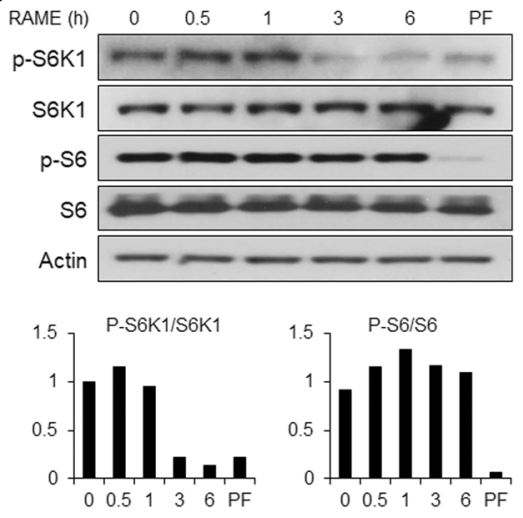

d
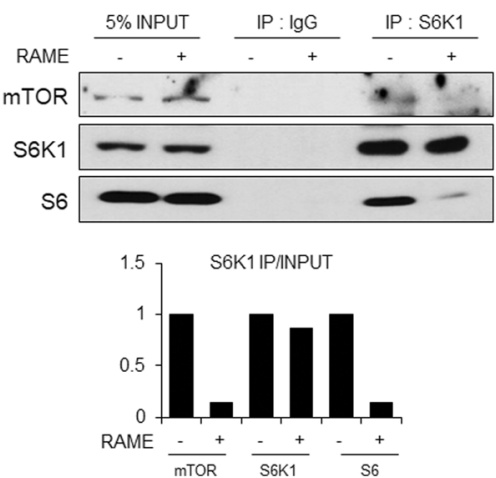

Fig. 3 RAME inhibits S6K1 signaling by blocking interaction with MTOR. a Immunoblotting analysis and quantification graphs of HeLa cells treated with each concentration of RAME for $24 \mathrm{~h}$. b Immunoblotting analysis and quantification graphs of HeLa cells treated with RAME (80 $\mu M$ ) for each time. c Immunoblotting analysis of HeLa (left) and SiHa (right) cells treated with RAME (40, $80 \mu \mathrm{M})$ for $24 \mathrm{~h}$. d Co-IP analysis and a quantification graph using an anti-lgG and S6K1 antibody in DMSO and RAME treated HeLa cells

detected using GFP antibody and immunoblotting data showed that treatment with RAME resulted in an increase in lipidated LC3-II in HeLa and SiHa cells (Fig. 4a, b). Endogenous LC3-II was elevated by RAME treatment and knockdown of S6K1, but the effects of RAME did not appear in S6K1-knockdown cells (Fig. 4c), showing that the lipidation of LC3 upon RAME treatment was mediated by S6K1 inhibition. We also observed the fluorescence signal from GFP-LC3 with a confocal microscope and found that LC3 puncta in autophagosomes were formed in HeLa and $\mathrm{SiHa}$ cells after treatment with RAME $(80 \mu \mathrm{M})$ for $24 \mathrm{~h}$ (Fig. 4d, e). Recent studies indicated that the transcriptional regulation of autophagy related genes is pivotal for autophagy. For example, the level of Atg8 determines autophagosome size [34] while that of Atg9 is proportional to their number [35], and the amount of Atg7 correlates with autophagy amplitude [36]. RAME treatment increased the mRNA levels of ATG genes (ULK1, ATG5, $B E C N 1, A T G 7, A T G 12$, and ATG13) dose dependently in cervical cancer cells (Fig. 4f, g). Taken together, these results indicate that RAME induces autophagy in cervical cancer cells.

\section{RAME induces apoptosis in cervical cancer cells} As suppressing the phosphorylation of S6K1 induces autophagic cell death [37], we examined the effect of RAME on apoptosis in HeLa and SiHa cells by detecting PARP-1 cleavage. The cleaved forms of PARP-1 were elevated in RAME-treated cervical cancer cells (Fig. 5a, b), which did not increase by RAME in S6K1-deficient cells (Fig. 5c). We also assessed the expression of a variety of tumor-suppressor genes that are associated with apoptosis (Bax, Noxa, and Puma), DNA repair (Gadd45 $\alpha$ ), or

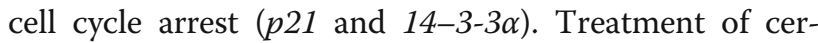
vical cancer cells with RAME induced transcription of apoptosis-related genes (Bax, Noxa, and Puma) and DNA repair gene (Gadd45 $\alpha$ ), whereas the mRNA levels of the cell cycle arrest genes ( $p 21$ and 14-3-3 $\alpha$ ) were not altered by RAME treatment (Fig. 5d, e). We also found that RAME significantly arrested the proliferation of both HeLa and SiHa cells as shown by measuring cell viability (Fig. 5f, g). Moreover, RAME treatment to HeLa cells upregulated the level of p53 level (Additional file 1: Figure S5A), resulting in the increase in apoptotic cell population (Additional file 1: Figure S5B). These results 

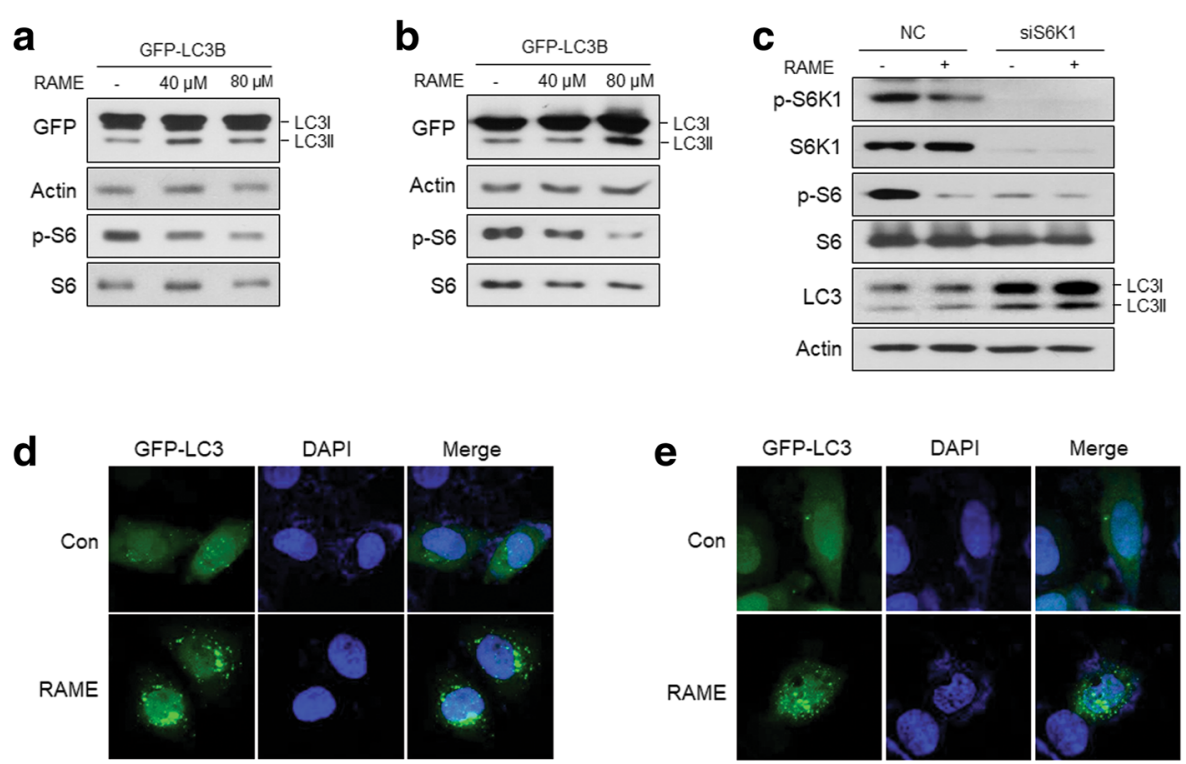

f
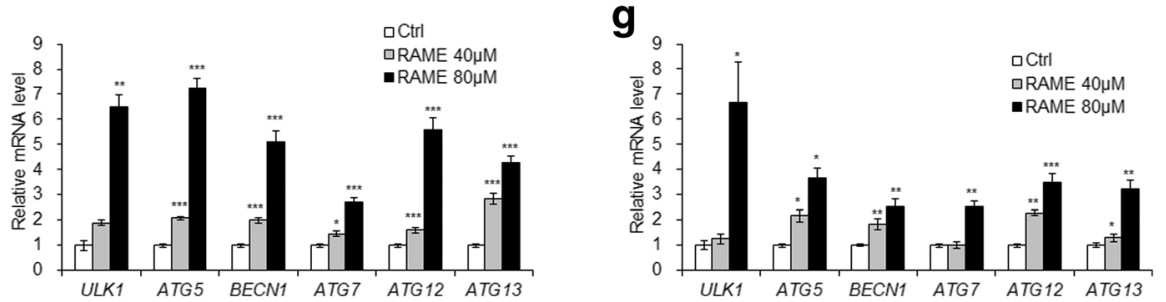

Fig. 4 RAME induces autophagy in cervical cancer cells. a and $\mathbf{b}$ Immunoblotting analysis of GFP-LC3B-expressing HeLa (a) and SiHa (b) cells treated with RAME (40 or $80 \mu \mathrm{M}$ ) for $24 \mathrm{~h}$. c Immunoblotting analysis of HeLa cells transfected with siRNA targeting S6K1 and treated with RAME $(80 \mu \mathrm{M})$ for $24 \mathrm{~h}$. (d and e) Fluorescent imaging of GFP-LC3B-expressing HeLa (d) and SiHa (e) cells treated with RAME ( $80 \mu \mathrm{M})$ for $24 \mathrm{~h}$. $\mathbf{f}$ and $\mathbf{g}$ The mRNA levels of autophagy-related genes in HeLa $(\mathbf{f})$ and SiHa $(\mathbf{g})$ cells treated with RAME (40 or $80 \mu \mathrm{M})$ for $24 \mathrm{~h}$. Error bars correspond to mean \pm SEM $(n=3) .{ }^{*} p<0.05,{ }^{* *} p<0.01,{ }^{* *} p<0.001$; unpaired t test

demonstrate that RAME induces apoptotic cell death by exerting an anti-proliferative effect.

\section{RAME enhances the effects of cisplatin in cervical cancer cells}

Cisplatin resistance is the biggest barrier to the successful treatment of cervical cancer [38]. Recent studies suggest that inhibiting the mTOR pathway overcome cisplatin resistance in several types of tumors [39-41]. As $\mathrm{SiHa}$ cells are less sensitive to cisplatin than HeLa cells [42], we compared the activation states of S6K1 and its downstream target, S6, in the two cell lines. The basal levels of phosphorylated S6K1 and S6 were higher in $\mathrm{SiHa}$ than those in HeLa cells (Fig. 6a). After cisplatin treatment, phosphorylation of S6K1 was dose-dependently increased in HeLa cells (Fig. 6b, left), whereas there was not much change in activation of S6K1 and S6 in SiHa cells (Fig. 6b, right). Therefore, we examined whether inhibition of S6K1 with RAME caused an increase in sensitivity to cisplatin. Treatment of SiHa cells with RAME ablated phosphorylation of both S6K1 and S6 also in the presence of cisplatin (Fig. 7a). Because the inhibition of S6K1 induced autophagy in cervical cancer, we investigated whether co-treatment with cisplatin and RAME induces autophagy more effectively than cisplatin alone. An immunoblotting assay with GFP-LC3B transfected SiHa cells showed that GFP-LC3-II, a lapidated form, increased more after cotreatment with cisplatin and RAME (Fig. 7b), which was also observed in endogenous LC3-II (Fig. 7a). The confocal microscopic image showed that the formation of the autophagosome was more detected after co-treatment with cisplatin and RAME in SiHa cells (Fig. 7c). Moreover, the transcription of autophagy-related genes was dramatically elevated after dual treatment compared to treatment with cisplatin alone (Fig. 7d), implying that combined treatment with cisplatin and RAME augmented autophagy in cisplatin resistant SiHa cells. Next, to confirm that RAME induces apoptosis after combined treatment, we assessed the expression of apoptotic genes. Consistent with the increase in autophagy, the mRNA levels of apoptosis related genes ( $\mathrm{Bax}$, Noxa, and Puma) and a DNA repair gene (Gadd45a) significantly increased after combination treatment (Fig. 7e). 


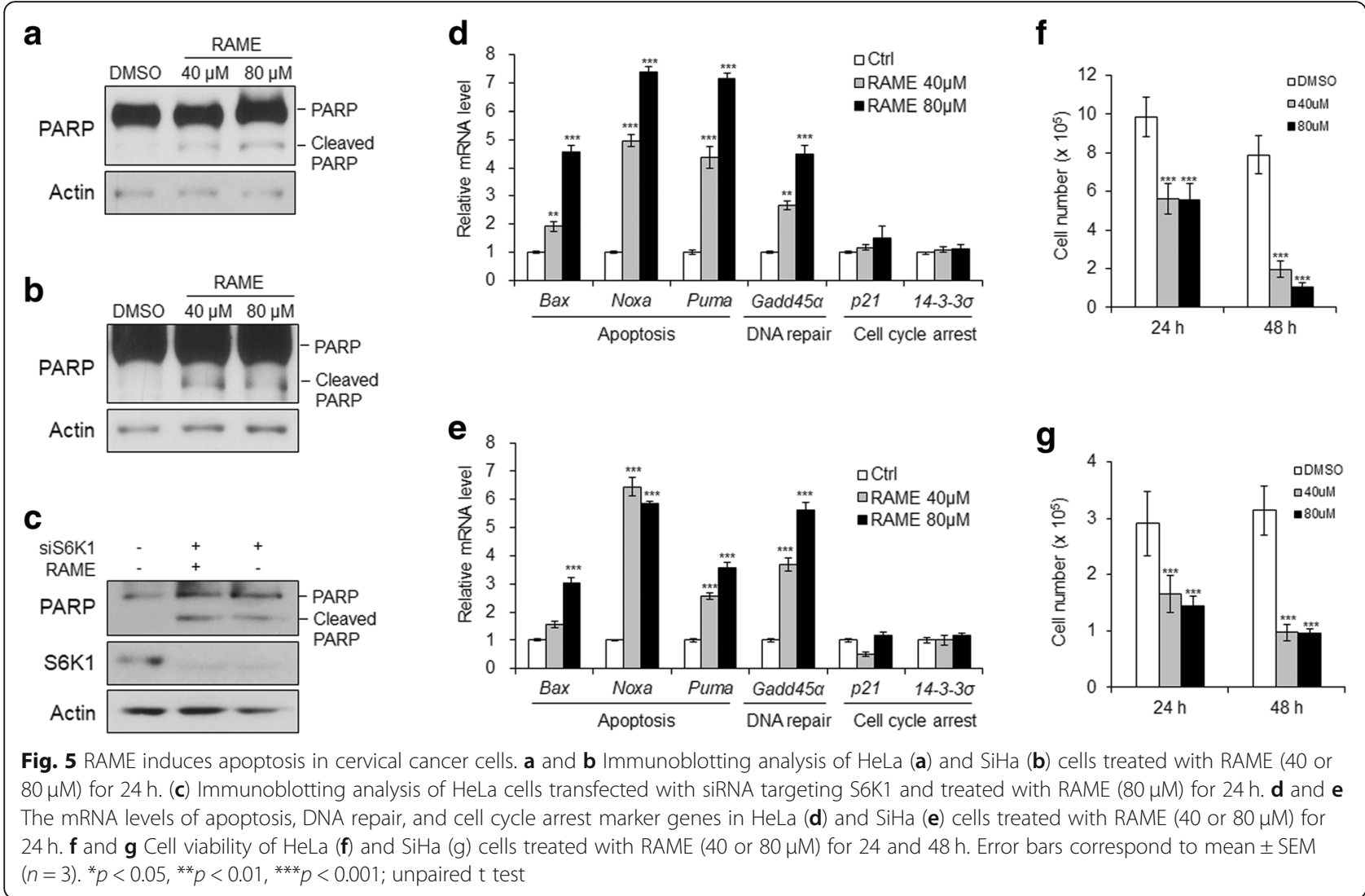

Treatment with RA, the parent compound of RAME, however, did not result in enhancing the expression of autophagy-related genes (Additional file 1: Figure S6A) or apoptotic genes (Additional file 1: Fig. S6B) when used in combination with cisplatin. Interestingly, cell cycle arrest genes $(p 21$ and $14-3-3 \alpha)$ increased only after RA treatment, but not after RAME treatment (Fig. 7e; Additional file 1: Figure S6B). The apoptotic marker, cleaved PARP-1, also increased after combination treatment (Fig. 7a). Moreover, clonogenic assay data showed that co-treatment with RAME enhanced the inhibitory effects of cisplatin against colony formation in both HeLa and SiHa cells (Fig. 7f). Lastly, we measured the cell viability of cisplatin-treated $\mathrm{SiHa}$ cells by co-treating with RAME at different concentrations. The $\mathrm{IC}_{50}$ values of cisplatin to block the survival of cervical cancer cells markedly decreased after RAME treatment (Fig. 7g). Collectively, these data imply that RAME enhances the effects of cisplatin in cervical cancer cells.
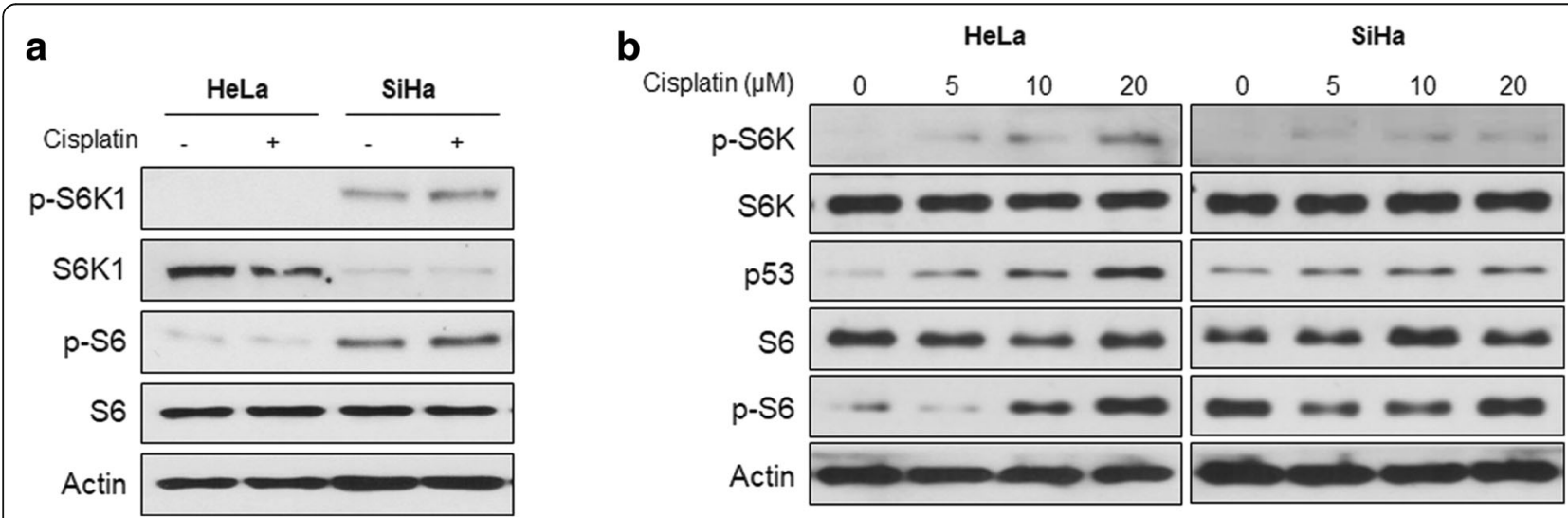

Fig. 6 S6K1 is activated in cisplatin-resistant cervical cancer cells. a Immunoblotting analysis of HeLa and SiHa cells treated with cisplatin (5 $\mu \mathrm{M})$ for $24 \mathrm{~h}$. b Immunoblotting analysis of HeLa and SiHa cells treated with cisplatin $(0,5,10,20 \mu \mathrm{M})$ for $24 \mathrm{~h}$ 


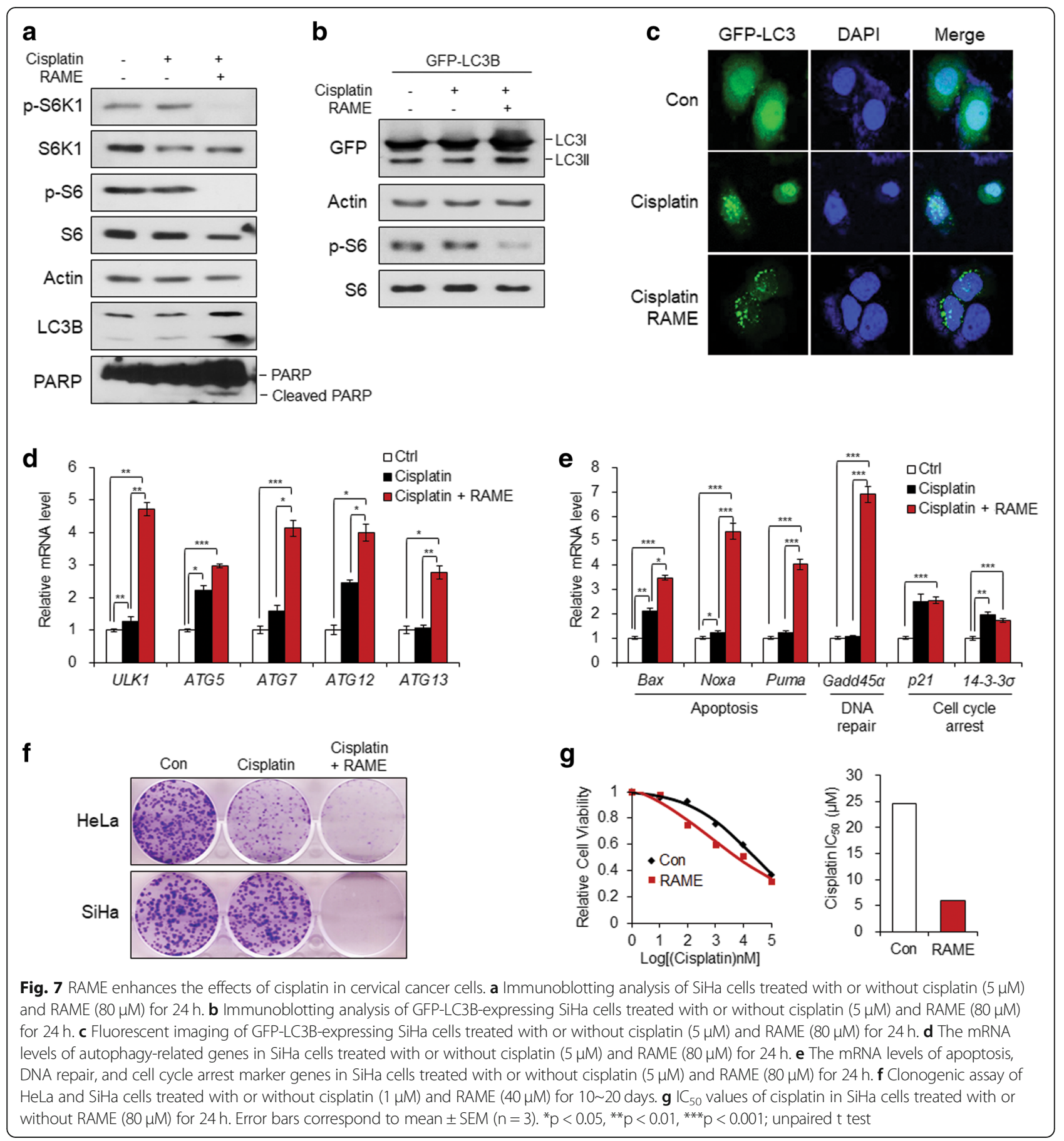

\section{Discussion}

In this study, we reveal that a natural compound rosmarinic acid methyl ester (RAME) exerts anti-cancer effects against cervical cancer by inhibiting mTOR/S6K1 pathway. The structure-based computational approach led to the identification of several small molecules, including RAME, which were expected to target S6K1. Successively through cell-based assays, we found that RAME effectively inhibits the activation of S6K1 by
mTOR, whereas rosmarinic acid cannot affect mTOR/ S6K1 signaling pathway. Rosmarinic acid (RA) is a natural polyphenolic substance found in various Lamiaceae herbs such as perilla [43], rosemary [44], sage [45], mint [46], basil [47], and thyme [48]. A number of studies have reported the biological effects of RA and one of its derivatives RAME, including anti-inflammatory $[49,50]$, anti-allergic [51, 52], and anti-microbial [53] effects. Additionally, here we evaluated the anti-tumor effects 
and mechanisms of action of RAME that were not observed after RA treatment (Additional file 1: Figure S6). Interestingly, there are several medicinal chemistry data demonstrating that the length of the alkyl side chain determines the bioactivity of RA derivatives [52-54]. According to our virtual screening data in Fig. 1b, methyl ester group of RAME enters the groove around Met225 of S6K1 properly, which is advantageous for VDW interaction.

mTOR pathway is a master regulator of cell growth/ size and protein synthesis that can lead to tumorigenesis [55]. Therefore, pharmacological inhibition of the mTOR signaling pathway is emerging as a useful therapeutic strategy for various cancers [56]. Several recent studies have shown that treatment with rapamycin, the most established mTOR/S6K1 inhibitor, induces autophagy and apoptotic cell death in cervical cancer cells as well as synergistic therapeutic responses in combination with cisplatin $[9,12,22]$. However, chronic use of rapamycin was found to cause unexpected insulin resistance $[57,58]$, which was mediated by impaired activation of the mTORC2/Akt pathway [59, 60]. Conversely, it was also reported that rapamycin enhances activation of Akt through a negative feedback loop [61]. These adverse effects of rapamycin necessitated the development of more specific mTORC1 inhibitors. As displayed in Fig. 3c and Additional file 1: Figure S4, RAME treatment for $24 \mathrm{~h}$ did not much alter the phosphorylation of Akt, suggesting that clinical and chronic use of RAME would provide more benefits and avoid the side effects on glucose homeostasis.

Occurrence of cisplatin resistance is a widespread phenomenon in cancer patients who have undergone platinum-based chemotherapy. Cancer cells that acquire cisplatin resistance lack apoptotic capacity with frequently observed abnormal activation of the Akt/mTOR pathway [19]. Our data also show that the treatment of cervical cancer cells with cisplatin induced activation of S6K1 and S6 (Fig. 6b), whose levels were already high in the cisplatin-resistant cervical cancer cell line (Fig. 6a). RAME treatment combined with cisplatin sensitized the resistant cells, reducing the $\mathrm{IC}_{50}$ value of cisplatin and promoting autophagy and apoptosis (Fig. $7 \mathrm{~g}$ ). Therefore, combining RAME with cisplatin can overcome tolerance and the adverse effects of high doses of cisplatin alone.

Cisplatin sensitivity is enhanced by co-treatment with mTOR inhibitors in various other cancers, including ovarian cancer [18, 19], lung cancer [20], and osteosarcoma $[21,24]$, as well as cervical cancer. The inactivation of S6K1 by treatment with RAME also occurred in the non-small cell lung cancer cell lines, A549 and H1299, though the effect was less in the cisplatin-resistant cell line, H1299 (Additional file 1: Figure S3). Further studies to explore the anti-tumor activity of RAME in lung cancer would broaden the applicable therapeutic range of RAME.

\section{Conclusions}

In summary, we elucidate the therapeutic potential of a newly found mTOR/S6K1 inhibitor, RAME, for the treatment of cervical cancer patients. Although the conventional mTOR inhibitor inevitably caused unpleasant side effects because of the additional inhibition of Akt, we here present that RAME specifically blocks the mTORC1/S6K1 signaling pathway without extra inhibition of Akt. Consequently, RAME induced the overexpression of multiple factors implicated in autophagy and apoptosis, leading to suppression of cell proliferation. Therefore, our findings suggest that RAME can be used as a promising anticancer agent for the treatment of cervical cancer, even when possessing chemoresistance.

\section{Additional file}

Additional file 1: Figure S1. Chemical structures of high-ranking virtual screening hits from both docking- and similarity-based method. Figure S2. RAME inhibits H2B phosphorylation by S6K1 in vitro. In vitro kinase assay with RAME was performed in a dose dependent manner using recombinant $\mathrm{H} 2 \mathrm{~B}$, active S6K1, and cold-ATP. Figure S3. Effects of RAME on lung cancer cell lines. Immunoblotting analysis of A549 and H1299 cells treated with RAME $(40,80 \mu \mathrm{M})$ for $24 \mathrm{~h}$. Figure S4. Effects of RAME and PF-4708671 on phosphorylation of Akt. Immunoblotting analysis of HeLa cells treated with RAME $(40 \mu \mathrm{M})$ or PF-4708671 $(20 \mu \mathrm{M})$ for $24 \mathrm{~h}$. Figure S5. RAME induces apoptosis in cervical cancer cells. (A) Immunoblotting analysis of HeLa cells treated with RAME (40 or $80 \mu \mathrm{M}$ ) for $24 \mathrm{~h}$. (B) Flow cytometric analysis of HeLa cells treated with RAME $(80 \mu \mathrm{M})$ for $24 \mathrm{~h}$. Figure S6. RA does not enhance the effects of cisplatin in cervical cancer cells. (A) The mRNA levels of autophagy-related genes in SiHa cells treated with or without cisplatin $(5 \mu \mathrm{M})$ and RA $(80 \mu \mathrm{M})$ for $24 \mathrm{~h}$. (B) The mRNA levels of apoptosis, DNA repair, and cell cycle arrest marker genes in SiHa cells treated with or without cisplatin $(5 \mu \mathrm{M})$ and $\mathrm{RA}(80 \mu \mathrm{M})$ for $24 \mathrm{~h}$. Error bars correspond to mean $\pm \mathrm{SEM}$ $(n=3) .{ }^{*} p<0.05,{ }^{* *} p<0.01,{ }^{* * *} p<0.001$; unpaired t test. (PPTX $\left.1004 \mathrm{~kb}\right)$

\section{Abbreviations}

GFP: Green fluorescent protein; HPV: Human papillomavirus; $I_{50}$ : The half maximal inhibitory concentration; LC3: Microtubule-associated protein 1A/1Blight chain 3; mTOR: Mammalian target of rapamycin; PARP: Poly (ADPribose) polymerase; RA: Rosmarinic acid; RAME: Rosmarinic acid methyl ester; S6K1: Ribosomal protein S6 kinase 1

\section{Acknowledgements}

Not applicable.

\section{Authors' contributions}

K.H.N., S.A.Y., J.W.H. conceived and designed the experiments. K.H.N., S.A.Y., G.N., J.S.N. performed experiments. J.W.P., M.G.L., J.H.P., H.O., J.L.1 (Jieun Lee), J.L.2 (Jaecheol Lee) provided experimental assistance and conceptual advice. K.R.L. offered compound library for structure-based screening. K.H.N., S.A.Y., H.J.P., J.W.H. help guide these studies and wrote the manuscript. All authors read and commented on the manuscript. All authors read and approved the final manuscript.

\section{Funding}

This research was financially supported through grants from the National Research Foundation of Korea (NRF) (2012R1A5A2A28671860,

2017R1A2B3002186, 2017R1A6A3A04001986, and 2019R1/1A1A01058903). The funding bodies did not directly participate in study design, data collection and analysis, or writing the manuscript.

\section{Availability of data and materials}

All data generated or analyzed during this study are reflected in the present published article and its supplementary information files. 


\section{Ethics approval and consent to participate}

Not applicable.

\section{Consent for publication}

Not applicable.

\section{Competing interests}

We declare that we have no competing interest.

Received: 12 February 2019 Accepted: 30 July 2019

Published online: 06 August 2019

\section{References}

1. Burd EM. Human papillomavirus and cervical cancer. Clin Microbiol Rev. 2003;16:1-17.

2. FUTURE II Study group. Quadrivalent vaccine against human papillomavirus to prevent high-grade cervical lesions. N Engl J Med. 2007;356:1915-27.

3. Hildesheim A, Herrero R, Wacholder S, Rodriguez AC, Solomon D, Bratti MC, Schiller JT, Gonzalez P, Dubin G, Porras C, Jimenez SE, Lowy DR. Costa Rican HPV vaccine trial group, effect of human papillomavirus 16/18 L1 viruslike particle vaccine among young women with preexisting infection: a randomized trial. JAMA. 2007;298:743-53.

4. Moore DH, Tian C, Monk BJ, Long HJ, Omura GA, Bloss JD. Prognostic factors for response to cisplatin-based chemotherapy in advanced cervical carcinoma: a gynecologic oncology group study. Gynecol Oncol. 2010;116:44-9.

5. Eskander RN, Tewari KS. Chemotherapy in the treatment of metastatic, persistent, and recurrent cervical cancer. Curr Opin Obstet Gynecol. 2014;26: 314-21

6. Wolford JE, Tewari KS. Rational design for cervical cancer therapeutics: cellular and non-cellular based strategies on the horizon for recurrent, metastatic or refractory cervical cancer. Expert Opin Drug Discov. 2018;26:1-13.

7. Movva S, Rodriguez L, Arias-Pulido H, Verschraegen C. Novel chemotherapy approaches for cervical cancer. Cancer. 2009;115:3166-80.

8. Zhang L, Wu J, Ling MT, Zhao L, Zhao KN. The role of the PI3K/Akt/mTOR signalling pathway in human cancers induced by infection with human papillomaviruses. Mol Cancer. 2015:14:87.

9. Faried LS, Faried A, Kanuma T, Aoki H, Sano T, Nakazato T, Tamura T, Kuwano $\mathrm{H}$, Minegishi $\mathrm{T}$. Expression of an activated mammalian target of rapamycin in adenocarcinoma of the cervix: a potential biomarker and molecular target therapy. Mol Carcinog. 2008;47:446-57.

10. Feng W, Duan X, Liu J, Xiao J, Brown RE. Morphoproteomic evidence of constitutively activated and overexpressed mTOR pathway in cervical squamous carcinoma and high grade squamous intraepithelial lesions. Int J Clin Exp Pathol. 2009;2:249-60.

11. Ji J, Zheng PS. Activation of mTOR signaling pathway contributes to survival of cervical cancer cells. Gynecol Oncol. 2010;117:103-8.

12. Molinolo AA, Marsh C, El Dinali M, Gangane N, Jennison K, Hewitt S, Patel V, Seiwert TY, Gutkind JS. mTOR as a molecular target in HPV-associated oral and cervical squamous carcinomas. Clin Cancer Res. 2012;18:2558-68.

13. Assad DX, Borges GA, Avelino SR, Guerra ENS. Additive cytotoxic effects of radiation and $\mathrm{mTOR}$ inhibitors in a cervical cancer cell line. Pathol Res Pract. 2018:214:259-62.

14. Xie G, Wang Z, Chen Y, Zhang S, Feng L, Meng F, Yu Z. Dual blocking of PI3K and mTOR signaling by NVP-BEZ235 inhibits proliferation in cervical carcinoma cells and enhances therapeutic response. Cancer Lett. 2017;388: 12-20.

15. Kelland $L$. The resurgence of platinum-based cancer chemotherapy. Nat Rev Cancer. 2007:7:573-84.

16. Small W Jr, Bacon MA, Bajaj A, Chuang LT, Fisher BJ, Harkenrider MM, Jhingran A, Kitchener HC, Mileshkin LR, Viswanathan AN, Gaffney DK. Cervical cancer: a global health crisis. Cancer. 2017;123:2404-12.

17. Galluzzi L, Senovilla L, Vitale I, Michels J, Martins I, Kepp O, Castedo M, Kroemer G. Molecular mechanisms of cisplatin resistance. Oncogene. 2012 31:1869-83.

18. Fraser M, Bai T, Tsang BK. Akt promotes cisplatin resistance in human ovarian cancer cells through inhibition of p53 phosphorylation and nuclear function. Int J Cancer. 2008;122:534-46.

19. Peng DJ, Wang J, Zhou JY, Wu GS. Role of the Akt/mTOR survival pathway in cisplatin resistance in ovarian cancer cells. Biochem Biophys Res Commun. 2010;394:600-5.
20. Wangpaichitr M, Wu C, You M, Kuo MT, Feun L, Lampidis T, Savaraj N. Inhibition of mTOR restores cisplatin sensitivity through down-regulation of growth and anti-apoptotic proteins. Eur J Pharmacol. 2008;591:124-7.

21. Xie ZG, Xie Y, Dong QR. Inhibition of the mammalian target of rapamycin leads to autophagy activation and cell death of MG63 osteosarcoma cells. Oncol Lett. 2013:6:1465-9.

22. Leisching $G R$, Loos B, Botha MH, Engelbrecht AM. The role of mTOR during cisplatin treatment in an in vitro and ex vivo model of cervical cancer. Toxicology. 2015;335:72-8

23. Gohr K, Hamacher A, Engelke LH, Kassack MU. Inhibition of PI3K/Akt/mTOR overcomes cisplatin resistance in the triple negative breast cancer cell line HCC38. BMC Cancer. 2017;17:711

24. Huang JC, Cui ZF, Chen SM, Yang LJ, Lian HK, Liu B, Su ZH, Liu JS, Wang M, Hu ZB, Ouyang JY, Li QC, Lu H. NVP-BEZ235 synergizes cisplatin sensitivity in osteosarcoma. Oncotarget. 2017;9:10483-96.

25. Niwa H, Mikuni J, Sasaki S, Tomabechi Y, Honda K, Ikeda M, Ohsawa N, Wakiyama M, Handa N, Shirouzu M, Honma T, Tanaka A, Yokoyama S. Crystal structures of the S6K1 kinase domain in complexes with inhibitors. J Struct Funct Genom. 2014;15:153-64.

26. Lemmen C, Lengauer T, Klebe G. FLEXS: a method for fast flexible ligand superposition. J Med Chem. 1998:41:4502-20.

27. Yi SA, Um SH, Lee J, Yoo JH, Bang SY, Park EK, Lee MG, Nam KH, Jeon YJ, Park JW, You JS, Lee SJ, Bae GU, Rhie JW, Kozma SC, Thomas G, Han JW. S6K1 phosphorylation of $\mathrm{H} 2 \mathrm{~B}$ mediates $\mathrm{EZH} 2$ trimethylation of $\mathrm{H} 3$ : a determinant of early adipogenesis. Mol Cell. 2016;62:443-52.

28. Pearce LR, Alton GR, Richter DT, Kath JC, Lingardo L, Chapman J. Characterization of PF-4708671, a novel and highly specific inhibitor of p70 ribosomal S6 kinase (S6K1). Biochem J. 2010;431:245-55.

29. Gump JM, Thorburn A. Autophagy and apoptosis: what is the connection? Trends Cell Biol. 2011;21:387-92.

30. Jung $\mathrm{CH}$, Ro SH, Cao J, Otto NM, Kim DH. mTOR regulation of autophagy. FEBS Lett. 2010:584:1287-95.

31. Hać A, Domachowska A, Narajczyk M, Cyske K, Pawlik A, Herman-Antosiewicz A. S6K1 controls autophagosome maturation in autophagy induced by sulforaphane or serum deprivation. Eur J Cell Biol. 2015;94:470-81.

32. Tanida I, Ueno T, Kominami E. LC3 and autophagy. Methods Mol Biol. 2008; 445:77-88.

33. Mizushima N. Autophagy: process and function. Genes Dev. 2007:21:2861-73.

34. Xie Z, Nair U, Klionsky DJ. Atg8 controls phagophore expansion during autophagosome formation. Mol Biol Cell. 2008;19:3290-8.

35. Jin M, He D, Backues SK, Freeberg MA, Liu X, Kim JK, Klionsky DJ. Transcriptional regulation by pho23 modulates the frequency of autophagosome formation. Curr Biol. 2014;24:1314-22.

36. Bernard A, Jin M, González-Rodríguez P, Füllgrabe J, Delorme-Axford E, Backues SK, Joseph B, Klionsky DJ. Rp.h1/KDM4 mediates nutrient-limitation signaling that leads to the transcriptional induction of autophagy. Curr. Biol. 2015:25:546-55.

37. Shin JH, Min SH, Kim SJ, Kim Yl, Park J, Lee HK, Yoo OJ. TAK1 regulates autophagic cell death by suppressing the phosphorylation of p70 S6 kinase 1. Sci Rep. 2013;3:1561

38. Chen J, Solomides C, Parekh H, Simpkins F, Simpkins H. Cisplatin resistance in human cervical, ovarian and lung cancer cells. Cancer Chemother Pharmacol. 2015:75:1217-27.

39. Wu C, Wangpaichitr M, Feun L, Kuo MT, Robles C, Lampidis T, Savaraj N. Overcoming cisplatin resistance by mTOR inhibitor in lung cancer. Mol Cancer. 2005;4:25

40. Choi HJ, Heo JH, Park JY, Jeong JY, Cho HJ, Park KS, Kim SH, Moon YW, Kim JS, An HJ. A novel PI3K/mTOR dual inhibitor, CMG002, overcomes the chemoresistance in ovarian cancer. Gynecol Oncol. 2019;153:135-48.

41. Tang XL, Yan L, Zhu L, Jiao DM, Chen J, Chen QY. Salvianolic acid a reverses cisplatin resistance in lung cancer $\mathrm{A} 549$ cells by targeting c-met and attenuating Akt/mTOR pathway. J Pharmacol Sci. 2017;135:1-7.

42. Venkatraman M, Anto RJ, Nair A, Varghese M, Karunagaran D. Biological and chemical inhibitors of NF-kappaB sensitize SiHa cells to cisplatin-induced apoptosis. Mol Carcinog. 2005:44:51-9.

43. Makino T, Ono T, Muso E, Honda G. Inhibitory effect of Perilla frutescens and its phenolic constituents on cultured murine mesangial cell proliferation. Planta Med. 1998:64:541-5.

44. al-Sereiti MR, Abu-Amer KM, Sen P. Pharmacology of rosemary (Rosmarinus officinalis Linn.) and its therapeutic potentials. Indian J. Exp. Biol. 1999:37: 124-30. 
45. Areias F, Valentão P, Andrade PB, Ferreres F, Seabra RM. Flavonoids and phenolic acids of sage: influence of some agricultural factors. J Agric Food Chem. 2000;48:6081-4.

46. Ellis $\mathrm{BE}$, Towers $\mathrm{GH}$. Biogenesis of rosmarinic acid in Mentha. Biochem J. 1970;118:291-7.

47. Tada H, Murakami Y, Omoto T, Shimomura K, Ishimaru K. Rosmarinic acid and related phenolics in hairy root cultures of ocimum basilicum. Phytochemistry. 1996;42:431-4.

48. Dapkevicius A, van Beek TA, Lelyveld GP, van Veldhuizen A, de Groot A, Linssen JP, Venskutonis R. Isolation and structure elucidation of radical scavengers from Thymus vulgaris leaves. J Nat Prod. 2002;65:892-6.

49. Amoah SK, Sandjo LP, Kratz JM, Biavatti MW. Rosmarinic acidpharmaceutical and clinical aspects. Planta Med. 2016;82:388-406.

50. Y. So, S.Y. Lee, A.R. Han, J.B. Kim, H.G. Jeong, C.H. Jin, Rosmarinic Acid Methyl Ester Inhibits LPS-Induced NO Production via Suppression of MyD88Dependent and -Independent Pathways and Induction of HO-1 in RAW 264. 7 Cells. Molecules 21, E1083 (2016).

51. Sanbongi C, Takano H, Osakabe N, Sasa N, Natsume M, Yanagisawa R, Inoue Kl, Sadakane K, Ichinose T, Yoshikawa T. Rosmarinic acid in perilla extract inhibits allergic inflammation induced by mite allergen, in a mouse model. Clin Exp Allergy. 2004;34:971-7.

52. Zhu F, Xu Z, Yonekura L, Yang R, Tamura H. Antiallergic activity of rosmarinic acid esters is modulated by hydrophobicity, and bulkiness of alkyl side chain. Biosci Biotechnol Biochem. 2015;79:1178-82.

53. A. Abedini, V. Roumy, S. Mahieux, M. Biabiany, A. Standaert-Vitse, C. Rivière, S. Sahpaz, F. Bailleul, C. Neut, T. Hennebelle, Rosmarinic Acid and Its Methyl Ester as Antimicrobial Components of the Hydromethanolic Extract of Hyptis atrorubens Poit. (Lamiaceae). Evid. Based Complement. Alternat. Med. (2013) doi: https://doi.org/10.1155/2013/604536.

54. Laguerre M, López Giraldo L, Lecomte J, Figueroa-Espinoza MC, Baréa B, Weiss J, Decker EA, Villeneuve P. Relationship between hydrophobicity and antioxidant ability of "phenolipids" in emulsion: a parabolic effect of the chain length of rosmarinate esters. J Agric Food Chem. 2010;58:2869-76.

55. Zoncu R, Efeyan A, Sabatini DM. mTOR: from growth signal integration to cancer, diabetes and ageing. Nat Rev Mol Cell Biol. 2011;12:21-35.

56. Faivre S, Kroemer G, Raymond E. Current development of mTOR inhibitors as anticancer agents. Nat Rev Drug Discov. 2006;5:671-88.

57. Teutonico A, Schena PF, Di Paolo S. Glucose metabolism in renal transplant recipients: effect of calcineurin inhibitor withdrawal and conversion to sirolimus. J Am Soc Nephrol. 2005;16:3128-35.

58. Di Paolo S, Teutonico A, Leogrande D, Capobianco C, Schena PF. Chronic inhibition of mammalian target of rapamycin signaling downregulates insulin receptor substrates 1 and 2 and AKT activation: a crossroad between cancer and diabetes? J Am Soc Nephrol. 2006;17:2236-44.

59. Veilleux A, Houde VP, Bellmann K, Marette A. Chronic inhibition of the mTORC1/S6K1 pathway increases insulin-induced PI3K activity but inhibits Akt2 and glucose transport stimulation in 3T3-L1 adipocytes. Mol Endocrinol. 2010;24:766-78

60. Lamming DW, Ye L, Katajisto P, Goncalves MD, Saitoh M, Stevens DM, Davis JG, Salmon AB, Richardson A, Ahima RS, Guertin DA, Sabatini DM, Baur JA. Rapamycin-induced insulin resistance is mediated by mTORC2 loss and uncoupled from longevity. Science. 2012;335:1638-43.

61. Wan X, Harkavy B, Shen N, Grohar P, Helman LJ. Rapamycin induces feedback activation of Akt signaling through an IGF-1R-dependent mechanism. Oncogene. 2007;26:1932-40.

\section{Publisher's Note}

Springer Nature remains neutral with regard to jurisdictional claims in published maps and institutional affiliations.

Ready to submit your research? Choose BMC and benefit from:

- fast, convenient online submission

- thorough peer review by experienced researchers in your field

- rapid publication on acceptance

- support for research data, including large and complex data types

- gold Open Access which fosters wider collaboration and increased citations

- maximum visibility for your research: over $100 \mathrm{M}$ website views per year

At BMC, research is always in progress.

Learn more biomedcentral.com/submissions 